medRxiv preprint doi: https://doi.org/10.1101/2021.03.15.21253595; this version posted March 24, 2021. The copyright holder for this preprint (which was not certified by peer review) is the author/funder, who has granted medRxiv a license to display the preprint in

It is made available under a CC-BY-NC-ND 4.0 International license.

\title{
The Effect of Diabetes and Prediabetes on Anti-tuberculosis Treatment Outcomes: A Multicentric Prospective Cohort Study
}

Authors: María B. Arriaga ${ }^{1,2,3^{*}}$, Mariana Araújo-Pereira ${ }^{1,2,3^{*}}$, Beatriz Barreto-Duarte ${ }^{1,2,4^{*}}$, Betânia Nogueira ${ }^{2,3,5^{*}}$, Maria Vitória C.N.S. Freire ${ }^{6}$, Artur T.L. Queiroz ${ }^{2,7}$, Moreno M.S. Rodrigues $^{8}$, Michael S. Rocha ${ }^{2,5}$, Alexandra B. Souza ${ }^{9,10}$, Renata Spener-Gomes ${ }^{9,10,11}$, Anna Cristina C. Carvalho ${ }^{12,13}$, Marina C. Figueiredo ${ }^{14}$, Megan M. Turner ${ }^{14}$, Betina Durovni ${ }^{15}$, José R. Lapa-e-Silva ${ }^{12}$, Afrânio L. Kritski ${ }^{12}$, Solange Cavalcante ${ }^{15}$, Valeria C. Rolla $^{16}$, Marcelo Cordeiro-Santos ${ }^{9,10,17}$, Timothy R. Sterling ${ }^{14}$, Bruno B. Andrade ${ }^{1,2,3,4,6,14}$ for the RePORT Brazil consortium ${ }^{\#}$.

"RePORT Brazil consortium (in addition to those listed above as main authors): Alice M. S. Andrade ${ }^{1,2}$, Vanessa Nascimento ${ }^{2,5}$, Hayna Malta-Santos ${ }^{1,3}$, Jéssica RebouçasSilva $^{1,3}$, Alysson G. Costa ${ }^{9,10}$, Jaquelane Silva ${ }^{9}$, Jamile G. de Oliveira ${ }^{15}$, Aline Benjamin ${ }^{16}$, Adriano Gomes-Silva ${ }^{16}$, Flavia M. Sant'Anna ${ }^{16}$, Francine P. Ignácio ${ }^{16}$, Maria Cristina Lourenço $^{18}$, Elisangela C. Silva ${ }^{12}$, Adriana S. R. Moreira ${ }^{12}$, Mayla Mello ${ }^{1}$

${ }^{1}$ Laboratório de Inflamação e Biomarcadores, Instituto Gonçalo Moniz, Fundação Oswaldo Cruz, Salvador, Brazil

${ }^{2}$ Multinational Organization Network Sponsoring Translational and Epidemiological Research (MONSTER) Initiative, Salvador, Brazil

${ }^{3}$ Faculdade de Medicina, Universidade Federal da Bahia, Salvador, Brazil

${ }^{4}$ Curso de Medicina, Universidade Salvador (UNIFACS), Salvador, Brazil

${ }^{5}$ Instituto Brasileiro para Investigação da Tuberculose, Fundação José Silveira, Salvador, Brazil

${ }^{6}$ Curso de Medicina, Escola Bahiana de Medicina e Saúde Pública (EBMSP), Salvador, Brazil

${ }^{7}$ Center of Data and Knowledge Integration for Health (CIDACS), Instituto Gonçalo Moniz, Fundação Oswaldo Cruz, Salvador, Brazil

${ }^{8}$ Laboratório de Análise e Visualização de Dados, Fundação Oswaldo Cruz, Porto Velho, Brazil

${ }^{9}$ Fundação Medicina Tropical Dr Heitor Vieira Dourado, Manaus, Brazil

${ }^{10}$ Programa de Pós-Graduação em Medicina Tropical, Universidade do Estado do Amazonas, Manaus, Brazil

11 Universidade Federal do Amazonas, Manaus, Brazil

${ }^{12}$ Programa Acadêmico de Tuberculose da Faculdade de Medicina, Universidade Federal do Rio de Janeiro, Rio de Janeiro, Brazil

${ }^{13}$ Laboratório de Inovações em Terapias, Ensino e Bioprodutos (LITEB), Instituto Oswaldo Cruz, Fiocruz, Rio de Janeiro, Brazil

${ }^{14}$ Division of Infectious Diseases, Department of Medicine, Vanderbilt University School of Medicine, Nashville, Tennessee, USA

${ }^{15}$ Secretaria Municipal de Saúde do Rio de Janeiro, Rio de Janeiro, Brazil

${ }^{16}$ Laboratório de Pesquisa Clínica em Micobacteriose, Instituto Nacional de Infectologia Evandro Chagas, Fiocruz, Rio de Janeiro, Brazil

${ }^{17}$ Universidade Nilton Lins, Manaus, Brazil

${ }^{18}$ Bacteriology and Bioassay Laboratory, National Institute of Infectious Diseases Evandro Chagas, Oswaldo Cruz Foundation, Rio de Janeiro, Brazil

"MBA, MA-P, BB-D and BN equally contributed to the work.

Correspondence: Bruno B. Andrade, MD, PhD, Laboratório de Inflamação e Biomarcadores, Instituto Gonçalo Moniz, Fundação Oswaldo Cruz, Rua Waldemar 
medRxiv preprint doi: https://doi.org/10.1101/2021.03.15.21253595; this version posted March 24, 2021. The copyright holder for this preprint (which was not certified by peer review) is the author/funder, who has granted medRxiv a license to display the preprint in It is made available under a CC-BY-NC-ND 4.0 International license

50 Falcão, 121, Candeal, Salvador, Bahia 40296-710, Brazil. Phone: +55-71-3176-2264 E51 mail: bruno.andrade@fiocruz.br

52 Keywords: Diabetes; Prediabetes; treatment outcome; SINAN; Mycobacterium 53 tuberculosis.

54 Running Head: Dysglycemia impacts TB treatment outcomes

40-word summary of the article's main point: In a multicenter prospective cohort study from Brazil, diabetes was associated with an increased risk of unfavorable treatment outcomes, including mortality, in pulmonary tuberculosis patients. These observations were validated in

58 the Brazilian National Disease Notification System during the same period.

59 Abstract word count: 200

60 Main MS text word count: 2895

61 Figures: 04

62 Tables: 02

63 Supplementary Figure: 02

64 Supplementary Tables: 04 
medRxiv preprint doi: https://doi.org/10.1101/2021.03.15.21253595; this version posted March 24, 2021. The copyright holder for this preprint (which was not certified by peer review) is the author/funder, who has granted medRxiv a license to display the preprint in It is made available under a CC-BY-NC-ND 4.0 International license

\section{ABSTRACT}

66 Background: It is unclear whether diabetes or prediabetes drives adverse treatment 67 outcomes and death in people with tuberculosis (PWTB).

68 Methods: Culture-confirmed PWTB, enrolled in the Regional Prospective Observational 69 Research in Tuberculosis (RePORT)-Brazil cohort between 2015 and 2019 ( $n=756)$ were 70 stratified based on glycemic status by baseline glycated hemoglobin levels. Unfavorable 71 TB outcome was defined as treatment failure or modification, recurrence or death, 72 whereas favorable outcome was cure or treatment completion. We validated the findings using data from PWTB reported to the Brazilian National System of Diseases Notification (SINAN) during 2015-2019 ( $n=20,989)$. Stepwise binary multivariable regression analysis models evaluated associations between glycemic status and unfavorable outcomes.

Results: In both cohorts, in univariate analysis, unfavorable outcomes were more frequently associated with drug resistance and HIV infection. Diabetes was associated with unfavorable outcomes in the RePORT (aOR: 2.85, p=0.001) and in SINAN (aOR: 1.56, $p=0.040$ ) cohorts. Furthermore, diabetes was associated with higher risk of death in both, RePORT-Brazil (aOR:3.23, p=0.006) and in the SINAN (aOR:2.75, p=0.047) cohorts.

Conclusion: Diabetes was associated with an increased risk of unfavorable outcomes and mortality in Brazilian PWTB. Interventions to improve tuberculosis treatment outcomes in persons with diabetes are needed. 
medRxiv preprint doi: https://doi.org/10.1101/2021.03.15.21253595; this version posted March 24, 2021. The copyright holder for this

preprint (which was not certified by peer review) is the author/funder, who has granted medRxiv a license to display the preprint in It is made available under a CC-BY-NC-ND 4.0 International license

85

86

87

\section{INTRODUCTION}

Diabetes (DM) is recognized by the World Health Organization (WHO) as a global epidemic [1]. This metabolic disease triples the risk of active tuberculosis (TB) in patients with latent Mycobacterium tuberculosis (Mtb) infection [2]. In 2019, approximately 400,000 people with tuberculosis (PWTB) worldwide were also diagnosed with diabetes [3] . Importantly, DM prevalence is increasing globally, including settings with a high (TB) burden, such as China and India [4].

The high prevalence of DM among TB patients $(10 \%-30 \%)$ in high TB burden countries and the negative impact of TB-DM comorbidity has been previously described by many groups [5-8] such as: higher mycobacterial loads and prevalence of sputum AFB positive, failure and death outcomes TB treatment, among others.

We have reported an association between DM and more severe TB clinical presentation (higher frequency of cough, night sweats, hemoptysis and malaise) [9], increased lung pathology reflected by severe radiographic manifestations (higher number of pulmonary lesions, including cavitation) [10], increased bacterial load in sputum [11] and delayed sputum conversion after anti-tuberculosis treatment initiation [12]. Furthermore, activation of tissue remodeling responses [12] and increased and persistent systemic inflammation [13] have been reported during treatment in TBDM patients. Thus, the increase in the number of people with DM may further complicate care and control of TB, especially in many areas with a high burden of both diseases [14].

There is also evidence that patients with concomitant TB and DM have an increased risk of unfavorable anti-tuberculosis treatment outcome such as failure, 
medRxiv preprint doi: https://doi.org/10.1101/2021.03.15.21253595; this version posted March 24, 2021. The copyright holder for this preprint (which was not certified by peer review) is the author/funder, who has granted medRxiv a license to display the preprint in It is made available under a CC-BY-NC-ND 4.0 International license

recurrence and death compared to normoglycemic patients [15-17]. However, the findings have not been consistent $[18,19]$. In the present study we evaluated the effect of dysglycemia (DM or pre-DM) on anti-tuberculosis treatment outcomes in a prospective Brazilian cohort of patients with pulmonary TB (Regional Prospective Observational Research in Tuberculosis (RePORT)-Brazil), and also among PWTB reported to the Brazilian National TB Registry through the National System of Diseases Notification (SINAN).

\section{MATERIALS AND METHODS}

\section{Ethics Statement}

The study was conducted according to the principles in the Declaration of Helsinki. The RePORT-Brazil protocol was approved by the institutional review boards at each study site and at Vanderbilt University Medical Center. The protocol, informed consent, and study documents were approved by the institutional review boards at all study sites. The Institional Review Boards and the protocol approval numbers are as follows: (i) Instituto de Pesquisa Clínica Evandro Chagas, Fundação Oswaldo Cruz, Rio de Janeiro, Brazil (protocol no. 688.067), (ii) Secretaria Municipal de Saude do Rio de Janeiro, Brazil (protocol no. 740.554), (iii) Hospital Universitario Clementino Fraga Filho Rio de Janeiro, Brazil (protocol no. 852.519), (iv) Maternidade Climério de Oliveira, Universidade Federal da Bahia, Salvador, Brazil (protocol no. 723.168), (v) Fundação de Medicina Tropical Dr. Heitor Vieira Dourado, Manaus, Brazil (protocol no. 807.595). Participation was voluntary and written informed consent was obtained from all participants. Participation in RePORT-Brazil was voluntary, and written informed consent was obtained from all 
medRxiv preprint doi: https://doi.org/10.1101/2021.03.15.21253595; this version posted March 24, 2021. The copyright holder for this

preprint (which was not certified by peer review) is the author/funder, who has granted medRxiv a license to display the preprint in It is made available under a CC-BY-NC-ND 4.0 International license

participants. All data extracted from SINAN were public and freely accessible. The anonymity of study subjects was preserved; all data were de-identified.

\section{Overall Study Design}

RePORT-Brazil includes five study sites, located in cities with high TB burden: Salvador, Manaus, and Rio de Janeiro [20]. One main objective of the consortium is to describe the clinical outcomes of TB treatment and latent Mtb infection in Brazil. The details of the sites and representativeness of the RePORT-Brazil cohort to all TB patients in Brazil have been described previously [20].

For the current analysis, we included RePORT-Brazil participants with pulmonary TB $\geq 18$ years old enrolled between June 2015 and June 2019 (Figure1A), with new or previously diagnosed culture-positive sputum (Lowenstein-Jensen medium or BD BACTEC MGIT), who received anti-tuberculosis treatment and had a treatment outcome recorded in the study database. Clinical and epidemiological information was collected at three in-person visits (i) anti-TB treatment initiation (baseline), (ii) two months after initiating treatment, and (iii) at the completion of anti-TB treatment. In addition, telephone follow-up was performed for all participants every 6 months until up to month 24 (when it corresponded). All data collected was stored in REDCap [21].

To establish the glycemic status of PWTB, baseline HbA1c in blood was measured.

DM was defined according to American Diabetes Association (ADA) guidelines [22]. Patients were classified as having DM ( $\mathrm{HbA} 1 \mathrm{c} \geq 6.5 \%)$, pre-diabetes (pre-DM; $\mathrm{HbA} 1 \mathrm{c} 1=5.7 \%-6.4 \%$ ) or normoglycemia $(\mathrm{HbA} 1 \mathrm{c}<5.7 \%)$. $\mathrm{HbA} 1 \mathrm{c} \geq 5.7 \%$ was classified as dysglycemia. 
medRxiv preprint doi: https://doi.org/10.1101/2021.03.15.21253595; this version posted March 24, 2021. The copyright holder for this preprint (which was not certified by peer review) is the author/funder, who has granted medRxiv a license to display the preprint in It is made available under a CC-BY-NC-ND 4.0 International license

SINAN is the Brazilian National System of Notification of Diseases [23], and includes diseases that require notification in all states and municipalities of Brazil; TB is a notifiable disease. The details of SINAN have been previously described [20]. PWTB reported to SINAN are diagnosed following the criteria in the Brazilian Manual of Recommendations for Tuberculosis control [24]. Diagnostic criteria include: (i) clinical and epidemiologic factors (presumptive diagnosis), (ii) bacteriology (sputum smear positive) or positive culture for Mtb (solid or liquid media), (iii) positive Xpert MTB RIF, (iv) chest radiography or (v) in the case of extrapulmonary TB, histopathology [24]. For each TB case reported, characteristics such as sex, age, race, education, alcohol consumption, illicit drug use, smoking habits, comorbidities, presence of HIV infection and test results, among others were also reported. Glycemic status was reported to SINAN as a diagnosis of diabetes (yes / no), not exclusively based on HbA1c level.

We used the SINAN information from the years 2015 to 2019 to match the enrollment period of RePORT-Brazil (see ref. [20] and Figure 1B). Of note, in 2014 the "Strategies for Care of people with Chronic diseases", addressing comprehensive basic care for patients with TB and DM among others [25], was implemented in Brazil. In addition, we used the sub-set of data reported from Salvador, Manaus, and Rio de Janeiro, the cities with RePORT Brazil study sites.

\section{Outcome definition}

177 The primary outcome in this study was an unfavorable treatment outcome defined as treatment modification, treatment failure, recurrence, or death (during treatment). The secondary outcome was mortality (death for any reason during 
medRxiv preprint doi: https://doi.org/10.1101/2021.03.15.21253595; this version posted March 24, 2021. The copyright holder for this preprint (which was not certified by peer review) is the author/funder, who has granted medRxiv a license to display the preprint in It is made available under a CC-BY-NC-ND 4.0 International license

treatment). All definitions of outcome treatments were established in accordance with the Manual of Recommendations for the Control of TB of Brazil [24]. The treatment outcome definitions used in RePORT-Brazil and SINAN are depicted in

Supplementary Table 1. A favorable outcome was defined as cure or treatment completion (defined as at least $90 \%$ of the total number of doses over one year for drug-susceptible TB and two years for TB-MDR). Patients who were lost to followup or transferred out or had a change in diagnosis (not a TB case) as the treatment outcome were excluded. The numbers of participants per outcome in this study are shown in more detail in Figure 1A and 1B.

\section{Data analysis}

All analyses were pre-specified. Median and interquartile ranges (IQR) were used as measures of central tendency. Categorical variables were represented as percentages and compared using a two-sided Pearson's chi-square test with Yates correction or the Fisher's two-tailed test in $2 \times 3$ or $2 \times 2$ tables, respectively. Quantitative variables were compared using the Mann Whitney $U$ test. We performed a logistic binary regression with backward stepwise selection in both the RePORT-Brazil and SINAN cohorts using variables with univariate p-values 0.2 to identify independent associations between characteristics of TB patients (one model for each stratification strategy of the glycemic status: dysglycemia, diabetes, prediabetes, and $\mathrm{HbA} 1 \mathrm{c}$ value) with the composite unfavorable treatment outcome or with mortality alone. Results from both regression approaches were presented in terms of point estimates and 95\% confidence intervals (Cl). P-values $<0.05$ were considered statistically significant. Statistical analyses were performed 
medRxiv preprint doi: https://doi.org/10.1101/2021.03.15.21253595; this version posted March 24, 2021. The copyright holder for this preprint (which was not certified by peer review) is the author/funder, who has granted medRxiv a license to display the preprint in It is made available under a CC-BY-NC-ND 4.0 International license. Diego, CA) and JMP 13.0 (SAS, Cary, NC, USA). 
medRxiv preprint doi: https://doi.org/10.1101/2021.03.15.21253595; this version posted March 24, 2021. The copyright holder for this preprint (which was not certified by peer review) is the author/funder, who has granted medRxiv a license to display the preprint in It is made available under a CC-BY-NC-ND 4.0 International license .

\section{RESULTS}

\section{Factors associated with tuberculosis treatment outcomes in RePORT-Brazil}

The RePORT cohort included 756 participants had culture-confirmed pulmonary

TB who were treated with anti-tuberculosis drugs for at least 6 months. Patients were grouped according to treatment outcomes: favorable $(n=654,86.5 \%)$ and unfavorable ( $\mathrm{n}=102,13.5 \%$ ) (Figure1A). The median age in RePORT cohort was 36 years [interquartile range (IQR): 25-49]. Most study participants were male in both groups. Patients with unfavorable outcomes more frequently reported current smoking $(p=0.03)$, alcohol consumption $(p=0.01)$ and illicit drug use $(p=0.001)$

(Table 1). These patients also had higher frequency of resistance to isoniazid $(p=0.006)$ or rifampicin $(p=0.002)$, multi-drug resistance $(p=0.009)$, diabetes $(p=0.003)$ and HIV infection $(p<0.001)($ Table 1$)$. The proportion of individuals with dysglycemia (i.e., with diabetes or prediabetes) did not differ significantly between those with unfavorable vs. favorable outcomes. In contrast, persons with unfavorable outcomes had lower hemoglobin levels (10.6 g/dL (IQR:8.98-12.4) vs.

1). In addition, no differences were found in the proportion of individuals with dysglycemia among those with drug-susceptible vs. multidrug resistant TB (Supplementary Table 2).

Regarding TB clinical presentation at study enrollment, patients who developed unfavorable outcomes more often were living with HIV $(p<0.001)$ and presented with fatigue $(p<0.001)$, whereas those who experienced a favorable treatment outcome more frequently presented with cough $(p<0.001)$ and hemoptysis $(p=0.043)$. (Supplementary Figure 1A and B). 
medRxiv preprint doi: https://doi.org/10.1101/2021.03.15.21253595; this version posted March 24, 2021. The copyright holder for this preprint (which was not certified by peer review) is the author/funder, who has granted medRxiv a license to display the preprint in It is made available under a CC-BY-NC-ND 4.0 International license

We next evaluated the impact of baseline glycemic status on treatment outcomes. Dysglycemia was more frequent in TB patients who failed therapy $(p=0.03)$ or died $(p=0.043)$ during TB treatment (Figure 2). Baseline Hb1Ac values were distinguishable between the subgroups of participants who further developed favorable and unfavorable outcome when the outcomes were examined individually (treatment modification, failure, death, recurrence, and cure). Individuals with favorable treatment outcomes had lower HbA1c levels than those who experienced treatment modification $(p=0.042)$, failure $(p=0.024)$, and death $(p=0.048)$ during treatment follow up. Among individuals with unfavorable outcomes, those who experienced treatment modification had lower $\mathrm{Hb} 1 \mathrm{Ac}$ values than patients who had treatment failure $(p=0.004)$ or died $(p=0.016)$ (Figure 2). Furthermore, TB patients who experienced failure, recurrence or died exhibited a median $\mathrm{HbA} 1 \mathrm{c}$ of $6 \mathrm{~g} / \mathrm{dL}$ (IQR:5.4-6.8).

\section{Determinants of TB treatment outcomes in Brazilian National System of}

\section{Notification of Diseases}

In the SINAN cohort, with data also collected from 2015 to 2019, 20,989 PWTB were notified in the three cities where RePORT study sites are located. Males represented more than $60 \%$ of patients in both groups, and patients with unfavorable outcomes were older (45 years, IQR:32-58, $p<0.001$ ), more frequently reported smoking $(p<0.001)$, alcohol consumption $(p<0.001)$, illicit drugs use $(p<0.001)$, and were less likely to report antiretroviral treatment (ART) $(p=0.009)$ than those with favorable outcome. Unfavorable outcome was associated with previous TB $(p<0.001)$, positive culture $(p<0.001)$, diabetes $(p=0.015)$, HIV co- 
medRxiv preprint doi: https://doi.org/10.1101/2021.03.15.21253595; this version posted March 24, 2021. The copyright holder for this preprint (which was not certified by peer review) is the author/funder, who has granted medRxiv a license to display the preprint in It is made available under a CC-BY-NC-ND 4.0 International license .

254 infection $(p<0.001)$, and other comorbidities $(p<0.001)$ (Table 2, Supplementary

255 Figure 1C).

256 Furthermore, we likewise evaluated the impact of glycemic status on the TB clinical 257 presentation by the study participants in both cohorts (Supplementary Figure 2). 258 In RePORT patients, weight loss was more commonly observed in PWDM than in 259 those with prediabetes or normoglycemia $(p<0.001)$. In patients from SINAN, there 260 was a higher proportion of PWTB with dysglycemia presenting with a positive smear at baseline than in those with normoglycemia $(p<0.001)$. In addition, frequency of HIV infection was higher in the normoglycemic patients from the SINAN dataset $(p<0.001)$. More details of other clinical factors are displayed in the Supplementary Figure 2.

Multivariable logistic regression to assess association between glycemic

\section{status and tuberculosis treatment outcomes}

A binomial logistic regression analysis was performed to test independent associations between the status of glycemia (dysglycemia, DM, pre-DM or HbA1c values) and treatment outcome in the RePORT cohort. DM was associated with unfavorable treatment outcomes independent of the other factors (adjusted OR [aOR]: 2.85, 95\% Cl: 1.57-5.17, $p=0.001$ ) (Figure 3, Model 2). This analysis also was performed in SINAN cohort and DM was independently associated with unfavorable TB treatment outcomes (aOR: 1.56, 95\% Cl: 1.04-2.52, $\mathrm{p}=0.04$ ) (Figure 3). 
medRxiv preprint doi: https://doi.org/10.1101/2021.03.15.21253595; this version posted March 24, 2021. The copyright holder for this preprint (which was not certified by peer review) is the author/funder, who has granted medRxiv a license to display the preprint in It is made available under a CC-BY-NC-ND 4.0 International license .

277

278

279

280

281

282

283

284

We next compared patients with favorable outcome versus those who died during TB treatment $(n=55)$. Mortality was associated with male sex $(p=0.039)$, increasing age $(p=0.002)$, pardo race $(61.8 \%, p=0.028)$, smoking $(p=0.011)$ and illicit drug use $(p=0.019)$, resistance to isoniazid $(p=0.02)$, to rifampicin $(p=0.004)$, multidrug resistance $(p=0.049)$, HIV infection $(p<0.001)$, diabetes $(p=0.005)$ and with lower concentrations of hemoglobin (death: $9.45 \mathrm{~g} / \mathrm{dL}$, IQR:7.95-10.99; cure:12.2, IQR:11-13.4, $\mathrm{p}<0.001$ ) and higher values of HbA1c (death:6.2\%, IQR:5.2-7.1; cure: 5.7\%, IQR: 5.4-6.2, $p<0.001$ ) (Supplementary Table 3).

In the SINAN cohort, the subgroup of "death" as outcome showed the same statistically significant variables than those detected when we compared the composite unfavorable outcome versus cure (Supplementary Table 4). Patients who were successfully treated were younger $(p<0.001)$, less likely to report smoking $(p<0.001)$, alcohol consumption $(p<0.002)$, illicit drug use $(p<0.018)$, HIV infection $(p<0.001)$ and other comorbidities $(p=0.009)$ in comparison to those who died during TB treatment in both cohorts. In SINAN, patients who developed a favorable outcome had a lower frequency of diabetes $(p=0.011)$ and higher frequency of ART use $(p=0.001)$.

A logistic regression analysis was performed comparing cure and death and presented similar results to the first model exploring the composite unfavorable outcome. In the RePORT cohort, DM was once again strongly associated with mortality (aOR: 3.23, 95\% $\mathrm{Cl}: 1.39-7.43, \mathrm{p}=0.006$ ) (Figure 4, Model 2). In the SINAN cohort, DM was also significantly associated with death (aOR: $2.75,95 \% \mathrm{Cl}$ : 1.02-7.42, $p=0.047$ ) (Figure 4). 
medRxiv preprint doi: https://doi.org/10.1101/2021.03.15.21253595; this version posted March 24, 2021. The copyright holder for this

preprint (which was not certified by peer review) is the author/funder, who has granted medRxiv a license to display the preprint in It is made available under a CC-BY-NC-ND 4.0 International license

300

301

302

303

304

305

306

307

308

309

310

311

312

313

314

315

316

317

\section{DISCUSSION}

There has recently been increased recognition of DM as an important risk factor for developing active TB and experiencing unfavorable TB treatment outcomes. $[14-16,26]$ As the prevalence of DM increases [27], particularly in developing countries, it is necessary to determine the public health impact of this syndemic in large populations. Our study analyzed data from PWTB in two data sources, a longitudinal cohort, and the nationwide disease notification system in the same period and the same three cities to determine the impact of DM on TB treatment outcomes in a Brazilian population.

It is interesting to note the factors that were consistently associated with poor outcomes in the two datasets analyzed, namely substance use (alcohol, tobacco, and illicit drug) and HIV infection, all in accordance with previous literature [19, 28] but different from other studies [29]. The analyses from RePORT also identified other drug resistance, anemia and normal chest radiograph as factors associated with worse outcomes. This latter observation may be due to the fact that RePORT performs systematic collection of these variables, which coincides with findings from other studies [19, 30].

In addition to the above factors, we found an association between higher $\mathrm{HbA} 1 \mathrm{c}$ levels and treatment modification, treatment failure and death, when compared with the HbA1c levels among TB patients who were successfully treated, and this was reflected in the significantly higher proportion of PWD among those with unfavorable anti-tuberculosis treatment outcomes. In the RePORT cohort, the odds of having an adverse outcome was 2.85 times higher in DM patients compared to normoglycemic individuals. An odds ratio of 1.56 was found in the SINAN dataset. The relative lower detection of DM cases in SINAN dataset 
medRxiv preprint doi: https://doi.org/10.1101/2021.03.15.21253595; this version posted March 24, 2021. The copyright holder for this preprint (which was not certified by peer review) is the author/funder, who has granted medRxiv a license to display the preprint in It is made available under a CC-BY-NC-ND 4.0 International license .

probably led to underestimation of the effect of DM in TB outcomes found in the analysis. Our results are similar to those from previous studies $[13,16]$. The odds of death in the DM groups were 3.23 times higher than in normoglycemic patients in RePORT dataset and 2.5 in SINAN dataset. The odds ratio of death in the RePORT cohort was more compatible with what has been described in literature [16]. Previous studies showed how TBDM comorbidity is associated with a higher burden of immune pathology and systemic inflammation compared to TB normoglycemic patients $[13,31]$. Furthermore, a defective regulation of the innate immune response in TBDM patients could maintain inflammatory foci despite antituberculosis treatment, resulting in worse treatment results [13].

Moreover, all participants from RePORT had HbA1c measured at baseline visit, whereas in SINAN the diagnosis of DM was self-reported in most cases, possibly missing many diagnoses. Of note, a longitudinal cohort study done in Brazil found that $50 \%$ of individuals diagnosed with DM did not know about their diagnosis [32]. Thus, in the SINAN cohort, with increasing clinical evidence that diabetes is a risk factor for developing active TB [2] and that worsens the clinical TB presentation [9], screening for diabetes was increased over the recent years. But the problem of under-diagnosis and sub-notification still exists.

The findings presented here suggest that the impact of DM in TB in Brazil is underestimated. While the results reiterate the value of cohorts like RePORT in better delineating the local epidemiology, it highlights the importance of guidelines recommending laboratory investigation of DM in all TB incident cases and to establish specific treatment recommendations for this population. This implies long-term glycemic control that is essential to improve the outcome of TB treatment in patients with TBDM comorbidity [33]. The integrated care of individuals with both 
medRxiv preprint doi: https://doi.org/10.1101/2021.03.15.21253595; this version posted March 24, 2021. The copyright holder for this

preprint (which was not certified by peer review) is the author/funder, who has granted medRxiv a license to display the preprint in It is made available under a CC-BY-NC-ND 4.0 International license

diseases has specific challenges such as the interaction between oral antidiabetic and anti-tuberculosis drugs [34] and the greater risk for adverse events [35].

We did not find an association between unfavorable outcome and death with preDM/dysglycemia in the RePORT cohort, but only with DM. Previous studies reported the normalization of glycemic levels during the treatment of TB, persons who were dysglycemic prior to anti-TB treatment $[36,37]$. Therefore, the deleterious effects on the immune response caused by chronic DM hyperglycemia would not be observed in pre-DM, which could explain the lack of association with unfavorable and death outcomes $[36,37]$.

This study had several limitations. First, both RePORT and SINAN are observational cohorts; unmeasured or residual confounding could have explained the findings. Second, SINAN is a disease notification system that is not part of a study protocol. While SINAN represents TB cases from all of Brazil, there could be incomplete data collection or endpoint ascertainment, as well as different sources of information (i.e., self-reported versus information from medical charts) for different patients. Third, we did not have information on serum drug levels; low drug levels have been associated with unfavorable TB treatment outcomes, including in TB patients with advanced HIV and DM [38]. Nevertheless, we believe it brings valuable information on the impact of TB-DM on a population level.

Diabetes is a disease with growing prevalence and a major risk factor for unfavorable outcomes, including death during treatment, in individuals with TB, along with HIV infection and substance use. Actions prioritizing these groups are essential for the control of TB in Brazil. 
medRxiv preprint doi: https://doi.org/10.1101/2021.03.15.21253595; this version posted March 24, 2021. The copyright holder for this preprint (which was not certified by peer review) is the author/funder, who has granted medRxiv a license to display the preprint in It is made available under a CC-BY-NC-ND 4.0 International license

373

374

375

\section{NOTES}

Acknowledgments: The authors thank the study participants. We also thank the teams of clinical and laboratory platforms of RePORT Brazil. A special thanks to Elze Leite (FIOCRUZ, Salvador, Brazil), Eduardo Gama (FIOCRUZ, Rio de Janeiro, Brazil), Elcimar Junior (FMT-HVD, Manaus, Brazil), Hilary Vansell (VUMC, Nashville, USA) and Letícia C.M. Linhares (VUMC, Nashville, USA) for administrative and logistical support.

Funding: The study was supported by the Intramural Research Program of the Fundação Oswaldo Cruz, Intramural Research Program of the Fundação José Silveira, Departamento de Ciência e Tecnologia (DECIT) - Secretaria de Ciência e Tecnologia (SCTIE) - Ministério da Saúde (MS), Brazil [25029.000507/2013-07] and the National Institutes of Allergy and Infectious Diseases [U01-Al069923]. M.B.A. received a fellowship from the Fundação de Amparo à Pesquisa da Bahia (FAPESB). M.A.-P. received a fellowship from Coordenação de Aperfeiçoamento de Pessoal de Nível Superior (Finance code: 001). B.B.A., J.R.L.S. and A.K. are senior investigators of the Conselho Nacional de Desenvolvimento Científico e Tecnológico (CNPq), Brazil.

Disclaimer: The funder of the study had no role in the study design, data collection, or data analysis; however, a representative of the Brazilian Ministry of Health (A.K.) was involved in data interpretation and writing the report.

Conflicts of interest: All authors: No reported conflicts of interest.

Author contributions: Conceptualization, T.R.S., M.C.F., M.C.S., V.C.R., and B.B.A.; Data curation, M.B.A., M.A-P., .A.T.L.Q., M.M.S.R., and B.B.A.; Investigation, M.B.A., B.B.-D., M.A-P., B.N., A.B.S., M.S.R., A.B., RS-G., M.C.F., 
medRxiv preprint doi: https://doi.org/10.1101/2021.03.15.21253595; this version posted March 24, 2021. The copyright holder for this preprint (which was not certified by peer review) is the author/funder, who has granted medRxiv a license to display the preprint in It is made available under a CC-BY-NC-ND 4.0 International license.

B.D., J.R.L.S., A.L.K., S.C., V.C.R., T.R.S., M.C.S., and B.B.A.; Formal analysis, M.B.A., M.A-P., A.T.L.Q., M.M.S.R. and B.B.A.; Funding acquisition, B.D., J.R.L.S., A.L.K., S.C., V.C.R., T.R.S., M.C.S., M.C.F., and B.B.A.; Methodology, M.B.A., B.B.-D., M.A-P and B.B.A.; Project administration, M.C.F., T.R.S., and B.B.A.; Resources, M.B.A., G.A., T.R.S., and B.B.A.; Software, M.B.A., M.A-P., A.T.L.Q., M.M.S.R., M.C.F., T.R.S., and B.B.A.; Supervision, T.R.S., and B.B.A.; Writing-original draft, M.B.A., B.B-D., M.A-P., B.N., M.V.C.N.S.F. and B.B.A.; Writing-review and editing, all authors. All authors have read and agreed to the submitted version of the manuscript. 


\section{REFERENCES}

1. World Health Organization. Global Report on Diabetes., 2016.

2. Jeon CY, Murray MB. Diabetes mellitus increases the risk of active tuberculosis: a systematic review of 13 observational studies. PLoS Med 2008; 5(7): e152.

3. World Health Organization. Global Tuberculosis Report 2020, 2020.

4. World Health Organization. Collaborative framework for care and control of tuberculosis and diabetes, 2011.

5. Cheng J, Zhang H, Zhao YL, Wang LX, Chen MT. Mutual Impact of Diabetes Mellitus and Tuberculosis in China. Biomed Environ Sci 2017; 30(5): 384-9.

6. Kreisel CF, Passannante MR, Lardizabal AA. The Negative Clinical Impact of Diabetes on Tuberculosis: A Cross-Sectional Study in New Jersey. J Endocr Soc 2019; 3(1): 62-8.

7. Kumar Nathella $\mathrm{P}$, Babu S. Influence of diabetes mellitus on immunity to human tuberculosis. Immunology 2017; 152(1): 13-24.

8. Sembiah S, Nagar V, Gour D, Pal DK, Mitra A, Burman J. Diabetes in tuberculosis patients: An emerging public health concern and the determinants and impact on treatment outcome. J Family Community Med 2020; 27(2): 91-6.

9. Gil-Santana L, Almeida-Junior JL, Oliveira CA, et al. Diabetes Is Associated with Worse Clinical Presentation in Tuberculosis Patients from Brazil: A Retrospective Cohort Study. PLoS One 2016; 11(1): e0146876.

10. Barreda NN, Arriaga MB, Aliaga JG, et al. Severe pulmonary radiological manifestations are associated with a distinct biochemical profile in blood of tuberculosis patients with dysglycemia. BMC Infect Dis 2020; 20(1): 139.

11. Almeida-Junior JL, Gil-Santana L, Oliveira CA, et al. Glucose Metabolism Disorder Is Associated with Pulmonary Tuberculosis in Individuals with Respiratory Symptoms from Brazil. PLoS One 2016; 11(4): e0153590.

12. Mesquita ED, Gil-Santana L, Ramalho D, et al. Associations between systemic inflammation, mycobacterial loads in sputum and radiological improvement after treatment initiation in pulmonary TB patients from Brazil: a prospective cohort study. BMC Infect Dis 2016; 16: 368.

13. Kumar NP, Fukutani KF, Shruthi BS, et al. Persistent inflammation during antituberculosis treatment with diabetes comorbidity. Elife 2019; 8.

14. Restrepo BI. Diabetes and Tuberculosis. Microbiol Spectr 2016; 4(6).

15. Dousa KM, Hamad A, Albirair M, et al. Impact of Diabetes Mellitus on the Presentation and Response to Treatment of Adults With Pulmonary Tuberculosis in Qatar. Open Forum Infect Dis 2019; 6(1): ofy335.

16. Huangfu P, Ugarte-Gil C, Golub J, Pearson F, Critchley J. The effects of diabetes on tuberculosis treatment outcomes: an updated systematic review and metaanalysis. Int J Tuberc Lung Dis 2019; 23(7): 783-96.

17. Yoon YS, Jung JW, Jeon EJ, et al. The effect of diabetes control status on treatment response in pulmonary tuberculosis: a prospective study. Thorax 2017; 72(3): 263-70.

18. Kornfeld H, Sahukar SB, Procter-Gray E, et al. Impact of Diabetes and Low Body Mass Index on Tuberculosis Treatment Outcomes. Clin Infect Dis 2020; 71(9): e392-e8.

19. Chaves Torres NM, Quijano Rodriguez JJ, Porras Andrade PS, Arriaga MB, Netto EM. Factors predictive of the success of tuberculosis treatment: A systematic review with meta-analysis. PLoS One 2019; 14(12): e0226507.

20. Arriaga MB, Amorim G, Queiroz ATL, et al. Novel Stepwise Approach to Assess Representativeness of a Large Multicenter Observational Cohort of Tuberculosis Patients: The Example of RePORT Brazil. Int J Infect Dis 2020.

21. Harris PA, Taylor R, Thielke R, Payne J, Gonzalez N, Conde JG. Research electronic data capture (REDCap)--a metadata-driven methodology and workflow 
process for providing translational research informatics support. J Biomed Inform 2009; 42(2): 377-81.

22. American Diabetes Association. Glycemic targets: Standards of Medical Care in Diabetes. Diabetes Care 2020; 42(Supplement 1): S187-S93.

23. Ministério da Saúde do Brasil, Secretaria de Vigilância em Saúde. Sistema de Informação de Agravos de Notificação. Available at: http://portalsinan.saude.gov.brl. Accessed 08-14-2020).

24. Ministério da Saúde do Brasil, Secretaria de Vigilância em Saúde. Manual de Recomendações para o Controle da Tuberculose no Brasil. 2013:288.

25. Estratégias para o cuidado da pessoa com doença crônica. Brazil: Cadernos de Atenção Básica, 2014:146.

26. Dooley KE, Chaisson RE. Tuberculosis and diabetes mellitus: convergence of two epidemics. Lancet Infect Dis 2009; 9(12): 737-46.

27. International Diabetes Federation. Diabetes Atlas. 9 ed, 2019.

28. Myers B, Bouton TC, Ragan EJ, et al. Impact of alcohol consumption on tuberculosis treatment outcomes: a prospective longitudinal cohort study protocol. BMC Infect Dis 2018; 18(1): 488.

29. Wang $Q$, Ma $A$, Han $X$, et al. Prevalence of type 2 diabetes among newly detected pulmonary tuberculosis patients in China: a community based cohort study. PLoS One 2013; 8(12): e82660.

30. Calderon RI, Arriaga MB, Lopez K, et al. High prevalence and heterogeneity of Dysglycemia in patients with tuberculosis from Peru: a prospective cohort study. BMC Infect Dis 2019; 19(1): 799.

31. Prada-Medina CA, Fukutani KF, Pavan Kumar N, et al. Systems Immunology of Diabetes-Tuberculosis Comorbidity Reveals Signatures of Disease Complications. Sci Rep 2017; 7(1): 1999.

32. Schmidt MI, Hoffmann JF, de Fatima Sander Diniz M, et al. High prevalence of diabetes and intermediate hyperglycemia - The Brazilian Longitudinal Study of Adult Health (ELSA-Brasil). Diabetol Metab Syndr 2014; 6: 123.

33. Critchley JA, Restrepo BI, Ronacher K, et al. Defining a Research Agenda to Address the Converging Epidemics of Tuberculosis and Diabetes: Part 1: Epidemiology and Clinical Management. Chest 2017; 152(1): 165-73.

34. Arbex MA, Varella Mde C, Siqueira HR, Mello FA. Antituberculosis drugs: drug interactions, adverse effects, and use in special situations. Part 1: first-line drugs. J Bras Pneumol 2010; 36(5): 626-40.

35. Siddiqui AN, Khayyam KU, Sharma M. Effect of Diabetes Mellitus on Tuberculosis Treatment Outcome and Adverse Reactions in Patients Receiving Directly Observed Treatment Strategy in India: A Prospective Study. Biomed Res Int 2016; 2016: 7273935.

36. Boillat-Blanco N, Ramaiya KL, Mganga M, et al. Transient Hyperglycemia in Patients With Tuberculosis in Tanzania: Implications for Diabetes Screening Algorithms. J Infect Dis 2016; 213(7): 1163-72.

37. Magee MJ, Salindri AD, Kyaw NTT, Auld SC, Haw JS, Umpierrez GE. Stress Hyperglycemia in Patients with Tuberculosis Disease: Epidemiology and Clinical Implications. Curr Diab Rep 2018; 18(9): 71.

38. Park JS, Lee JY, Lee YJ, et al. Serum Levels of Antituberculosis Drugs and Their Effect on Tuberculosis Treatment Outcome. Antimicrob Agents Chemother 2016; 60(1): 92-8. 
medRxiv preprint doi: https://doi.org/10.1101/2021.03.15.21253595; this version posted March 24, 2021. The copyright holder for this preprint (which was not certified by peer review) is the author/funder, who has granted medRxiv a license to display the preprint in

It is made available under a CC-BY-NC-ND 4.0 International license.

509

510

511

\section{TABLES}

Table 1. Characteristics of persons with TB in the RePORT-Brazil cohort by treatment outcomes

\begin{tabular}{|c|c|c|c|}
\hline Characteristics & $\begin{array}{c}\text { Unfavorable } \\
(n=102)\end{array}$ & $\begin{array}{c}\text { Favorable } \\
(n=654)\end{array}$ & p-value \\
\hline Male, n (\%) & $71(69.6)$ & $415(63.5)$ & 0.267 \\
\hline Age, median (IQR) & $38(27-52)$ & $36(25-49)$ & 0.208 \\
\hline Race, n (\%) & & & 0.050 \\
\hline White & $18(17.6)$ & $147(22.5)$ & \\
\hline Black & $22(21.6)$ & $168(25.7)$ & \\
\hline Asian & $0(0)$ & $4(0.6)$ & \\
\hline Pardo & $57(55.9)$ & $325(49.8)$ & \\
\hline Indigenous & $5(4.9)$ & $9(1.4)$ & \\
\hline Illiterate, n (\%) & $97(95.1)$ & $626(95.7)$ & 0.793 \\
\hline Smoking, $\mathrm{n}(\%)^{\mathrm{a}}$ & $66(64.7)$ & $317(48.5)$ & 0.030 \\
\hline Alcohol consumption, $\mathrm{n}(\%)^{\mathrm{b}}$ & $94(92.2)$ & $537(82.1)$ & 0.010 \\
\hline Illicit drug use, $n(\%)^{c}$ & $44(43.1)$ & $176(26.9)$ & 0.001 \\
\hline Prior TB, n (\%) & $17(16.8)$ & $110(16.9)$ & 1 \\
\hline Type of TB, $n(\%)^{d}$ & & & 0.235 \\
\hline PTB & $87(85.3)$ & $585(89.4)$ & \\
\hline PTB+EPTB & $15(14.7)$ & $69(10.6)$ & \\
\hline Abnormal X-ray, n (\%) & $95(93.1)$ & $639(97.7)$ & 0.020 \\
\hline Positive smear, n (\%) & $81(79.4)$ & $528(80.7)$ & 0.788 \\
\hline \multicolumn{4}{|l|}{ Resistance, n (\%) } \\
\hline Isoniazid & $13(13.1)$ & $33(5.2)$ & 0.006 \\
\hline Rifampicin & $8(8.1)$ & $11(1.7)$ & 0.002 \\
\hline Any drug ${ }^{e}$ & $11(11.1)$ & $71(11.1)$ & 1 \\
\hline Multidrug $^{f}$ & $6(6.1)$ & $9(1.4)$ & 0.009 \\
\hline DOT, n (\%) & $53(51.9)$ & $368(56.3)$ & 0.543 \\
\hline \multicolumn{4}{|l|}{ Glycemic status, $\mathbf{n}(\%)$} \\
\hline Diabetes & $37(36.3)$ & $128(19.6)$ & 0.003 \\
\hline Prediabetes & $25(24.5)$ & $230(35.2)$ & 0.43 \\
\hline Normoglycemia & $40(39.2)$ & $296(45.3)$ & Ref. \\
\hline Dysglycemia, n (\%) & $62(60.8)$ & $358(54.7)$ & 0.284 \\
\hline Metformin use, $n(\%)^{g}$ & $2(5.4)$ & $9(7.0)$ & 0.516 \\
\hline Hemoglobin (g/dL), median (IQR) & $10.6(8.98-12.4)$ & $12.2(10.95-13.4)$ & $<0.001$ \\
\hline HbA1c (\%), median (IQR) & $6(5.4-6.8)$ & $5.7(5.4-6.2)$ & 0.054 \\
\hline HIV status, n (\%) & $45(44.6)$ & $100(15.5)$ & $<0.001$ \\
\hline ART, n (\%) & $13(28.9)$ & $34(33.7)$ & 0.702 \\
\hline Hypertension, n (\%) & $11(10.8)$ & $56(8.6)$ & 0.455 \\
\hline Other comorbidities, $\mathbf{n}(\%)^{\mathrm{i}}$ & $13(12.7)$ & $32(4.9)$ & $<0.001$ \\
\hline
\end{tabular}

Table Note: Data represent $\mathrm{n}$. (\%) or median with Interquartile range (IQR).

Favorable: cure/complete treatment. Unfavorable: failure, recurrence, treatment modification or death. 
medRxiv preprint doi: https://doi.org/10.1101/2021.03.15.21253595; this version posted March 24, 2021. The copyright holder for this preprint (which was not certified by peer review) is the author/funder, who has granted medRxiv a license to display the preprint in It is made available under a CC-BY-NC-ND 4.0 International license

or crack). ${ }^{d}$ All individuals from the RePORT cohort had a diagnosis of pulmonary tuberculosis, in some cases with presence in other anatomical sites. ${ }^{e}$ Any drug (anti-tuberculosis) resistance except rifampicin and isoniazid: Pyrazinamide, ethambutol, streptomycin, kanamycin, ethionamide. ${ }^{f}$ Multidrug: TB caused by Mycobacterium Tuberculosis (M. tuberculosis) strains that are resistant to at least both rifampicin and isoniazid.Only patients with the diabetes condition used metformin. ${ }^{9}$ The frequency of use of metformin was calculated only in patients with diabetes. ${ }^{\text {h} A R T ~ f r e q u e n c y ~ w a s ~ c a l c u l a t e d ~ a m o n g ~ t h e ~ p e r s o n s ~ l i v i n g ~ w i t h ~ H I V . ~}{ }^{i}$ It include cancer, kidney disease, chronic obstructive pulmonary disease, emphysema, and asthma. Abbreviations: TB: Tuberculosis. PTB: Pulmonary TB. EPTB: Extrapulmonary TB. HIV: Human Immunodeficiency Virus. DOT: Directly Observed Therapy. ART: Antiretroviral therapy. 
medRxiv preprint doi: https://doi.org/10.1101/2021.03.15.21253595; this version posted March 24, 2021. The copyright holder for this preprint (which was not certified by peer review) is the author/funder, who has granted medRxiv a license to display the preprint in perpetuity.

It is made available under a CC-BY-NC-ND 4.0 International license .

Table 2. Characteristics of people with TB in the SINAN (2015-2019) cohort by outcomes

\begin{tabular}{|c|c|c|c|}
\hline Characteristics & $\begin{array}{c}\text { Unfavorable } \\
(n=260)\end{array}$ & $\begin{array}{l}\text { Favorable } \\
(n=23747)\end{array}$ & p-value \\
\hline Male, n (\%) & $177(68.1)$ & $13010(62.8)$ & 0.082 \\
\hline Age, median (IQR) & $39(32-49)$ & $38(28-52)$ & 0.217 \\
\hline Race, n (\%) & & & 0.674 \\
\hline White & $64(26.7)$ & $5116(26.4)$ & \\
\hline Black & $56(23.3)$ & $3495(18.1)$ & \\
\hline Asian & $4(1.7)$ & $170(0.9)$ & \\
\hline Pardo & $116(48.3)$ & $10500(54.3)$ & \\
\hline Indigenous & $0(0)$ & $62(0.3)$ & \\
\hline Illiterate, n (\%) & $35(19.1)$ & $2422(15.3)$ & 0.147 \\
\hline Smoking, $\mathbf{n}(\%)^{\mathrm{a}}$ & $68(30)$ & $3540(18)$ & $<0.001$ \\
\hline Alcohol consumption, $\mathrm{n}(\%)^{\mathrm{b}}$ & $53(23.3)$ & $2600(13.1)$ & $<0.001$ \\
\hline Illicit drug use, $n(\%)^{\mathrm{c}}$ & $40(17.8)$ & $1873(9.6)$ & $<0.001$ \\
\hline Prior TB, n (\%) & $101(38.8)$ & 3209 (15.5) & $<0.001$ \\
\hline Type of TB, $n(\%)^{d}$ & & & 0.107 \\
\hline PTB & $247(95)$ & $20071(96.8)$ & \\
\hline EPTB & $4(1.5)$ & $117(0.6)$ & \\
\hline PTB+EPTB & $9(3.5)$ & $541(2.6)$ & \\
\hline Abnormal X-ray, n (\%) & $220(97.8)$ & $17914(97.3)$ & 1 \\
\hline Positive smear, n (\%) & $157(80.9)$ & $10718(76.3)$ & 0.150 \\
\hline Positive culture, n (\%) & $116(85.9)$ & $5877(71.2)$ & $<0.001$ \\
\hline Resistance, n (\%) & & & $<0.001$ \\
\hline Isoniazid & $34(13.7)$ & $76(0.3)$ & $<0.001$ \\
\hline Rifampicin & $7(2.7)$ & $9(0.03)$ & $<0.001$ \\
\hline Any drug ${ }^{\mathrm{e}}$ & $40(15.4)$ & $145(55.8)$ & $<0.001$ \\
\hline Multidrug $^{f}$ & $12(4.6)$ & $13(0.05)$ & $<0.001$ \\
\hline DOT, n (\%) & $112(64.7)$ & $10107(60.6)$ & 0.275 \\
\hline Diabetes, $n(\%)$ & $36(15.4)$ & $2066(10.4)$ & 0.015 \\
\hline HIV infection, $\mathbf{n}(\%)$ & $46(21.3)$ & $1906(10.6)$ & $<0.001$ \\
\hline ART, n (\%) ${ }^{g}$ & $23(50)$ & $1225(64.3)$ & 0.009 \\
\hline Hypertension, n (\%) & $5(1.9)$ & $567(2.7)$ & 0.564 \\
\hline Other comorbidities, $\mathbf{n}(\%)^{\mathrm{h}}$ & $23(9.1)$ & $804(4.0)$ & $<0.001$ \\
\hline
\end{tabular}

Table Note: Data represent $\mathrm{n}$. (\%) or median with Interquartile range (IQR).

Favorable: cure/complete treatment. Unfavorable: failure, recurrence, treatment modification or death.

aSmoking habits: Past or current cigarette smoker. ${ }^{b}$ Alcohol consumption: Past or current any consumption of alcohol. ' ${ }^{\prime l l i c i t ~ d r u g ~ u s e: ~ P a s t ~ o r ~ c u r r e n t ~ i l l i c i t ~ d r u g ~ u s e ~(m a r i j u a n a, ~ c o c a i n e, ~ h e r o i n ~}$

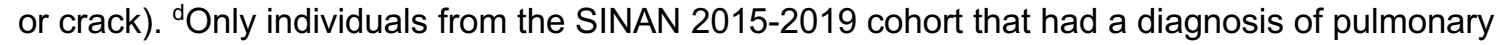
tuberculosis, in some cases with presence in other anatomical sites, were included. ${ }^{e}$ Any drug (anti-tuberculosis) resistance except rifampicin and isoniazid: Pyrazinamide, ethambutol, streptomycin, kanamycin, ethionamide. ${ }^{\mathrm{f}}$.Multidrug: TB caused by Mycobacterium Tuberculosis strains that are resistant to at least both rifampicin and isoniazid. ${ }^{9} \mathrm{ART}$ frequency was calculated among the persons living with HIV. ${ }^{\mathrm{h}}$ It include cancer, kidney disease, chronic obstructive pulmonary disease, emphysema, and asthma. 
medRxiv preprint doi: https://doi.org/10.1101/2021.03.15.21253595; this version posted March 24, 2021. The copyright holder for this preprint (which was not certified by peer review) is the author/funder, who has granted medRxiv a license to display the preprint in It is made available under a CC-BY-NC-ND 4.0 International license

Abbreviations: TB: Tuberculosis. PTB: Pulmonary TB. EPTB: Extrapulmonary TB. HIV: Human Immunodeficiency Virus. DOT: Directly Observed Therapy. ART: Antiretroviral therapy. 


\section{FIGURES AND LEGENDS}

\section{Figure 1: Study flowchart.}

Flowchart presenting the PWTB included and excluded from (A) RePORT-Brazil and PWTB reported to (B) SINAN between 2015- 2019.

Abbreviations: RePORT: Regional Prospective Observational Research for Tuberculosis. SINAN: Sistema de Informação de Agravos de Notificação. TB: Tuberculosis.

Figure 2. Distribution of the glycemic status and Hb1Ac levels according to treatment outcomes in TB patients in RePORT-Brazil.

Frequency of PWTB with diabetes, prediabetes, normoglycemia and dysglycemia (diabetes + prediabetes) diagnosed using $\mathrm{HbA} 1 \mathrm{c}$ levels is shown according to the TB treatment outcomes (cure, treatment modification, failure, death, and recurrence). Only comparisons (frequency dysglycemia status between TB treatment outcomes) with significant $p$-values are displayed. Scatter plots depicting the frequency of $\mathrm{HbA} 1 \mathrm{c}$ values in TB patients according to TB treatment outcome. Lines represent median and interquartile range values. The differences in median values $\mathrm{HbA} 1 \mathrm{c}$ between groups were compared using the Kruskal-Wallis test with Dunn's multiple comparisons post-test. Only comparisons with significant $p$-values are displayed. Abbreviations: HbA1c: glycated hemoglobin, normoglyc.: normoglycemia

Figure 3. Association between glycemic status and TB treatment outcomes among TB patients from RePORT-Brazil and SINAN cohorts.

In Report-Brazil cohort (upper panel) logistic regression models (backward stepwise regression) were performed to evaluate the independent associations between glycemic status of tuberculosis patients (Model 1: dysglycemia, Model 2: diabetes, Model 3: prediabetes and Model 4: increases of 1 unit in $\mathrm{HbA} 1 \mathrm{c}$ level) and variables with $\mathrm{p}$-value $<0.2$ results in the univariate analyses (Table 1) and unfavorable treatment outcome (treatment modification, failure, recurrence, and death). In SINAN cohort (lower panel) logistic regression models (backward stepwise regression) were performed to evaluate the independent associations between diabetes of tuberculosis and variables with $p$-value $<0.2$ results in the univariate analyses (Table 2 ) and unfavorable treatment outcome (treatment modification, failure, and death).

Abbreviations: RePORT: Regional Prospective Observational Research for Tuberculosis. SINAN: Sistema de Informação de Agravos de Notificação. TB: Tuberculosis. MDR-TB: multidrug-resistant tuberculosis. IDU: illicit drug use. PTB: pulmonary tuberculosis. HbA1c: glycated hemoglobin.

\section{Figure 4. Association between glycemic status and death during anti-tuberculosis} treatment among TB patients from RePORT-Brazil and SINAN cohorts.

In Report-Brazil cohort (upper panel) logistic regression models (backward stepwise regression) were performed to evaluate the independent associations between glycemic status of tuberculosis patients (Model 1: dysglycemia, Model 2: diabetes, Model 3: prediabetes and Model 4: increases of 1 unit in $\mathrm{HbA} 1 \mathrm{c}$ level) and variables with $\mathrm{p}$-value $<0.2$ results in the univariate analyses (Supplementary Table 3) and death.

In SINAN cohort (lower panel) logistic regression models (backward stepwise regression) were performed to evaluate the independent associations between diabetes of tuberculosis patients in the period 2015-2019 and variables with $p$-value $<0.2$ results in the univariate analyses (Supplementary Table 4) and death.

Abbreviations: RePORT: Regional Prospective Observational Research for Tuberculosis. SINAN: Sistema de Informação de Agravos de Notificação (Brazilian National System of Notification of Diseases) TB: Tuberculosis. HbA1c: glycated hemoglobin. 

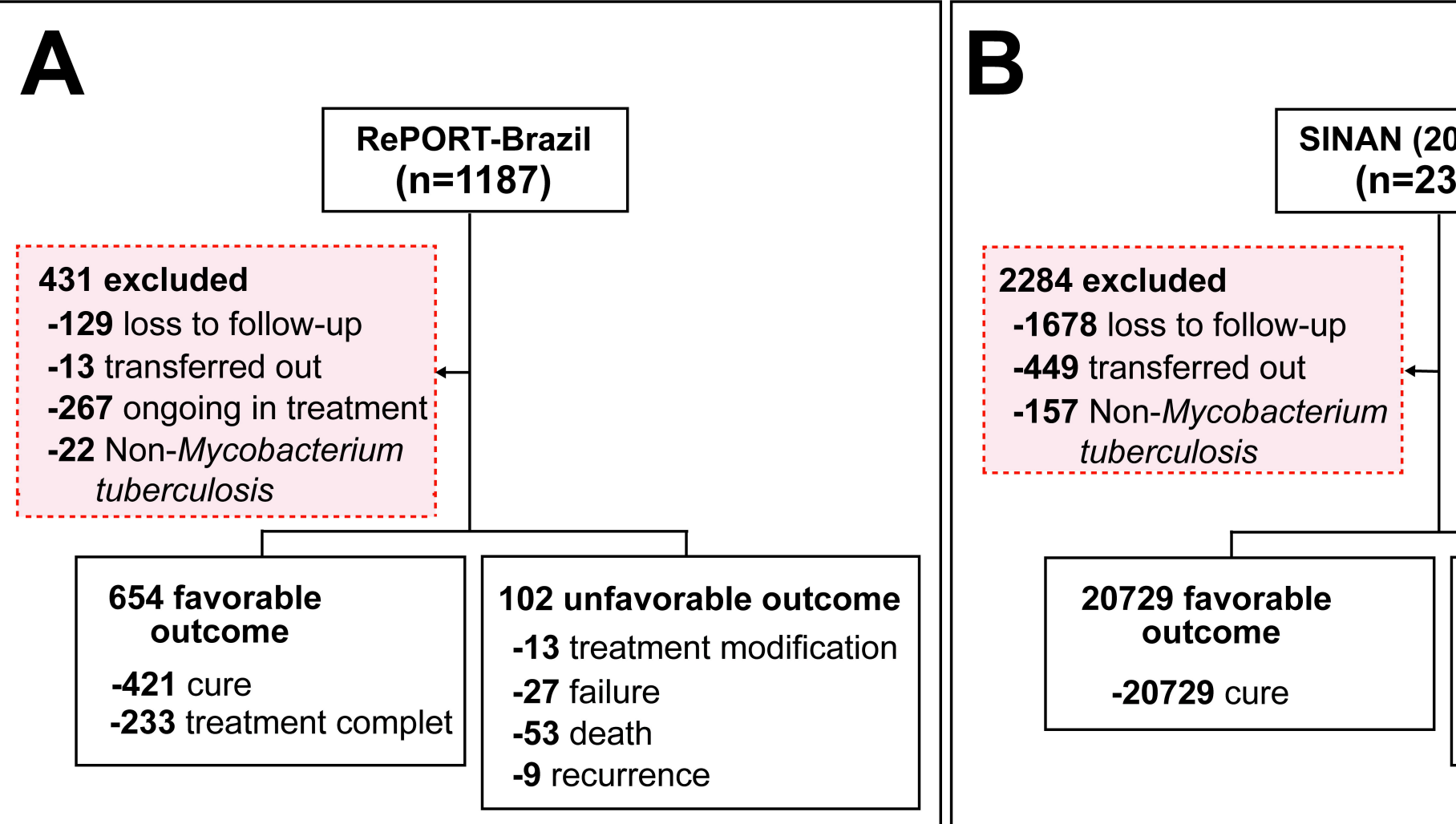

260 unfavorable outcome

-140 treatment modification -9 failure

-111 death 


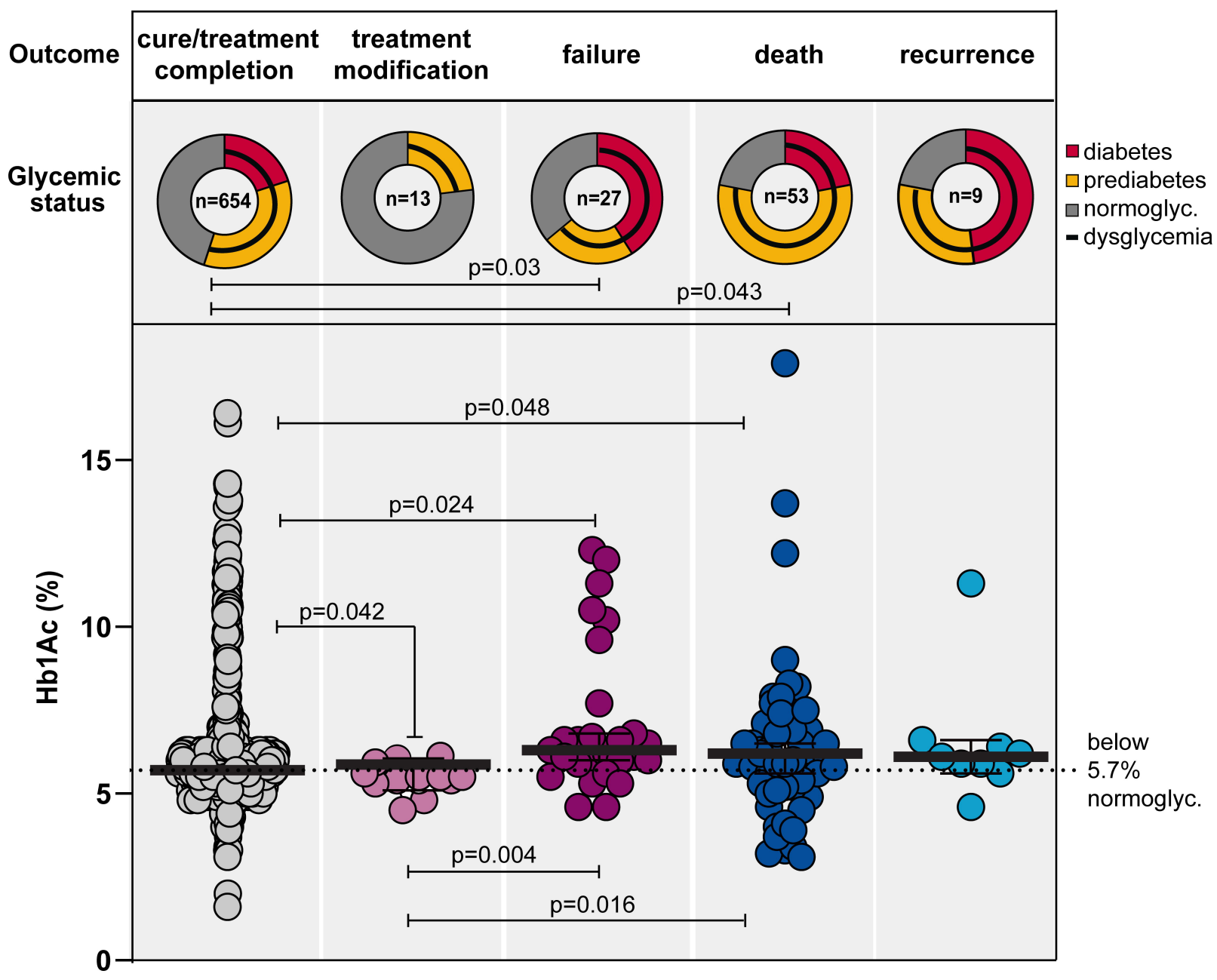




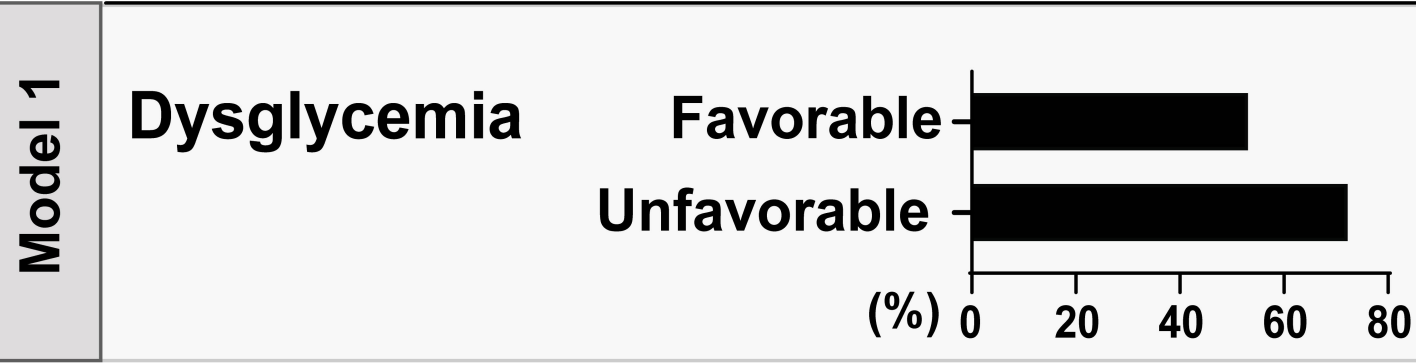

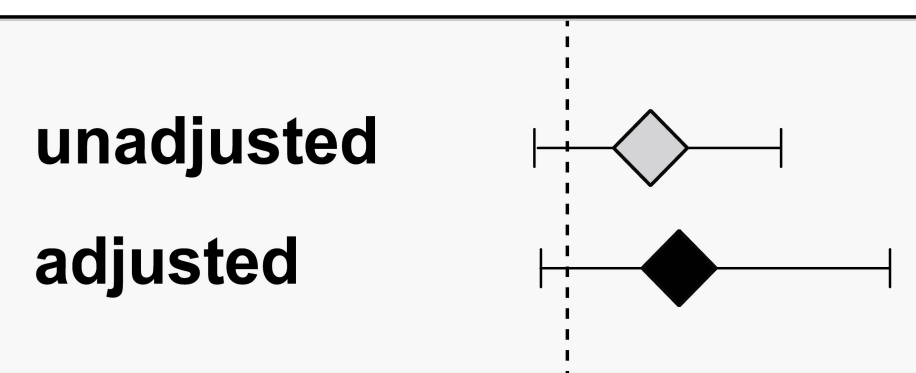

$$
\begin{array}{ll}
1.28(0.84-1.96) & 0.284 \\
1.43(0.86-2.34) & 0.163
\end{array}
$$

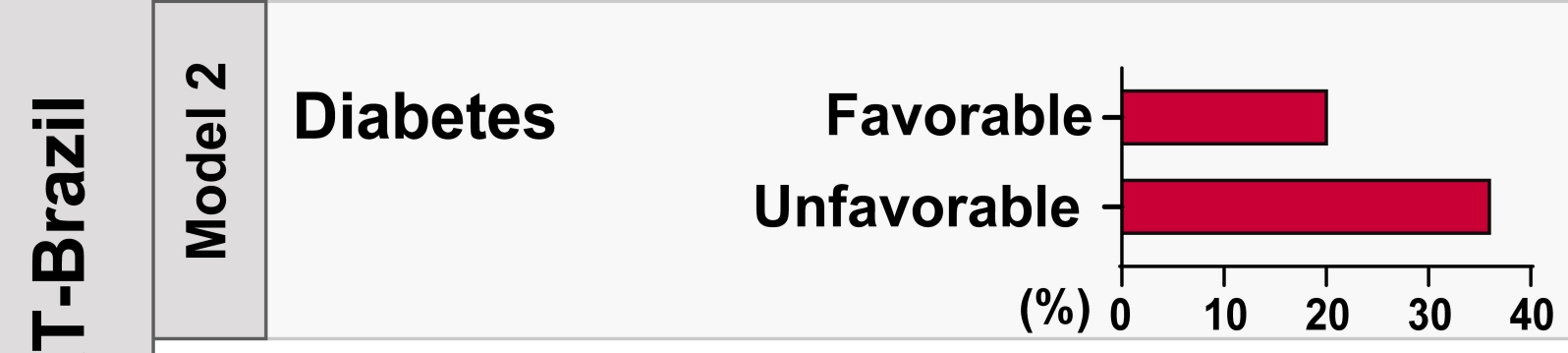

$$
\begin{aligned}
& \text { unadjusted } \\
& \text { adjusted }
\end{aligned}
$$

$2.14(1.31-3.50) \quad 0.003$

$2.85(1.57-5.17) \quad 0.001$

$\frac{m}{0}$
$\frac{0}{0}$
$\frac{0}{\Sigma}$

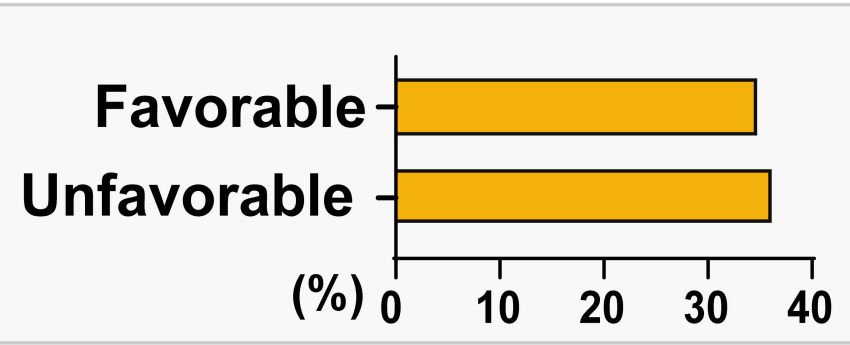

unadjusted

adjusted

$0.80(0.47-1.37)$

0.430

(\%) $0 \begin{array}{lllll} & 10 & 20 & 30 & 40\end{array}$

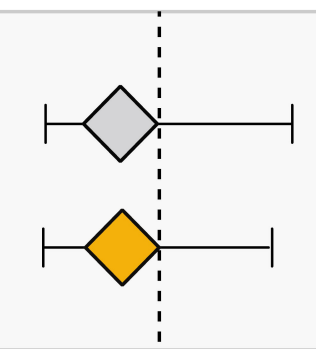

$0.81(0.43-1.52) \quad 0.523$

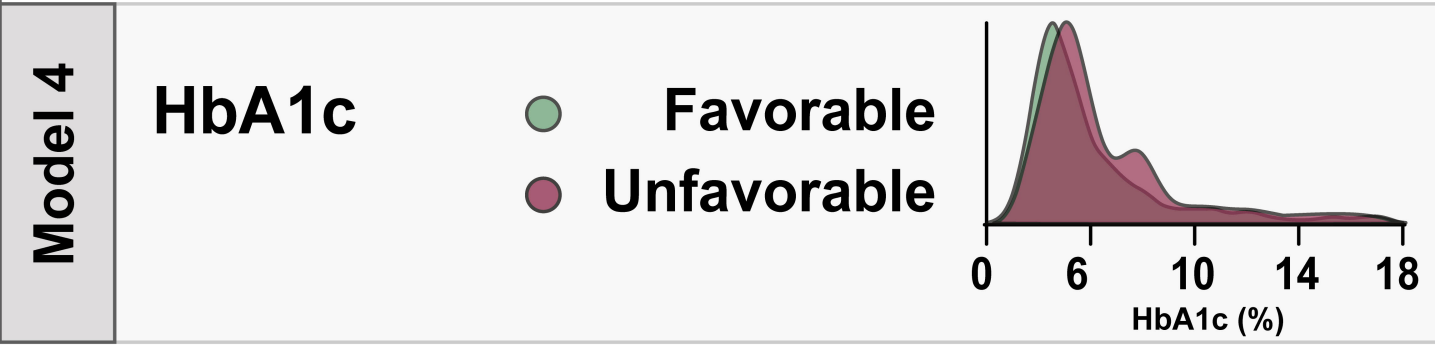

\section{unadjusted \\ adjusted}

1.04 (0.94-1.14) 0.054

$1.10(0.99-1.21) \quad 0.060$
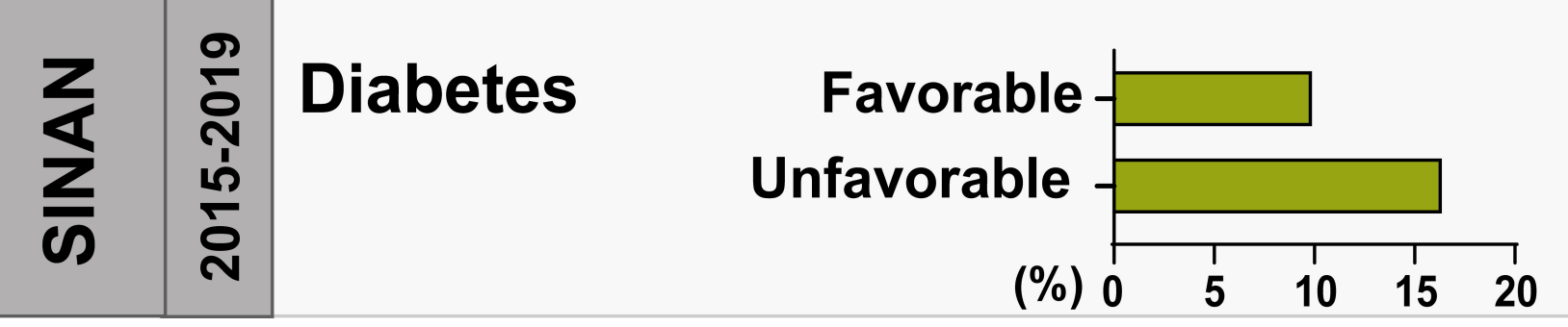
unadjusted
adjusted

$1.57(1.10-2.24) \quad 0.015$

$1.56(1.04-2.52) \quad 0.040$

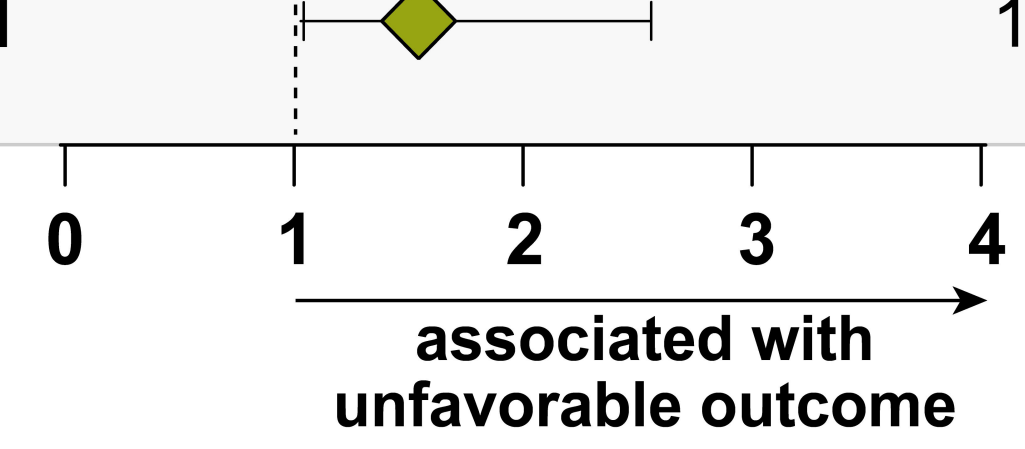


